\title{
Cytological aspects of the infection process of Pyricularia oryzae on leaves of wheat plants supplied with silicon
}

\author{
Rodrigo Silva Sousa, Fabrício Ávila Rodrigues, Daniel Augusto Schurt, Naiara Fernandes Abreu \\ Souza \& Maria Fernanda Antunes Cruz
}

Departamento de Fitopatologia, Universidade Federal de Viçosa, 36570-000, Viçosa, MG, Brazil

Author for correspondence: Fabrício Ávila Rodrigues, e-mail: fabricio@ufv.br

\begin{abstract}
Blast, caused by Pyricularia oryzae, has become one of the most important diseases on wheat in Brazil. Knowing the beneficial effects of silicon $(\mathrm{Si})$ in reducing rice blast severity, this study aimed to examine the cytological events occurring during the infectious process of $P$. oryzae on the leaves of wheat plants non-supplied $(-\mathrm{Si})$ or supplied (+Si) with $\mathrm{Si}$ in an experiment arranged in a completely randomized design. The high foliar Si concentration for the + Si plants contributed to decrease the blast symptoms. Hyphae of $P$. oryzae grew successfully and formed an extensively branched mycelium in the first-invaded epidermal cell and invaded several neighboring cells on the -Si plants, while on the + Si plants fungal hyphae was restricted to the first-invaded epidermal cell. The number of brown adaxial epidermal cells and their intensity of browning were significantly lower for the +Si plants in comparison to the -Si plants. The frequency of appressorial sites showing type B reaction (infection hyphae within the epidermal cell and absence of cytoplasm granulation) was lower for the +Si plants than for the -Si plants from 72 to 96 hours after inoculation because the frequency of appressorial sites showing type A reaction (unsuccessful penetration) was kept higher in comparison to the -Si plants. This study provides novel cytological evidence of the negative effect of Si on the infection process of $P$. oryzae on leaves of wheat plants contributing, therefore, to reduce the blast symptoms. Key words: Triticum aestivum, host resistance, light microscopy, mineral nutrition, wheat blast.
\end{abstract}

\section{INTRODUCTION}

Wheat blast, caused by Pyricularia oryzae (Cooke) Sacc., was first discovered in Paraná State in 1985 (Igarashi et al., 1986) and since then it has become one of the major diseases affecting wheat (Triticum aestivum L.) production in Brazil. The major blast symptoms occur on spikes and spikelets as gray-brown lesions. Spike tip death and bright black spots on the rachis are often observed (Goulart et al., 2007). On leaves, blast symptoms are gray-green and water-soaked lesions with dark green borders that become light tan in color with necrotic borders after they have completely expanded (Debona et al., 2012).

Blast control is very difficult to achieve due to the absence of cultivars with race-specific resistance and efficient fungicides (Goulart et al., 2007). Therefore, new strategies for disease control need to be urgently investigated. Considering that wheat plants can contain high silicon $(\mathrm{Si})$ concentration (values ranging from 0.9 to up to $1.5 \mathrm{dag} / \mathrm{kg}$ ) in shoot dry weight (Rafi \& Epstein, 1999; Xavier Filha et al., 2011; Debona et al., 2012), Si application may be a viable method of enhancing wheat resistance against diseases, especially to blast. Xavier Filha et al. (2011) were the first to demonstrate that wheat plants supplied with $\mathrm{Si}$ showed reduced blast symptoms. According to the authors, the resistance of wheat plants supplied with Si to blast was due to the high concentration of lignin and high activities of chitinases and peroxidases. Domiciano et al. (2010) showed that the area under the spot blotch progress curve decreased and the activities of chitinases and peroxidades were higher on leaves of wheat plants supplied with Si. Wheat plants supplied with Si showed reduced powdery mildew (Blumeria graminis f.sp. tritici) symptoms due to more papilla formation and deposition of electron-dense osmiophilic material, identified as glycosilated phenolics and aglycone compounds, that altered haustoria integrity on the epidermal cells (Bélanger et al., 2003; RémusBorel et al., 2005). Leaf blotch (Septoria tritici) and foot rot (Fusarium spp.) on wheat has been also efficiently controlled by supplying Si to the plants (Rodgers-Gray \& Shaw, 2000).

Root and foliar diseases affecting barley, corn, cucumbers, grapes, strawberries, soybean, rice and rye are effectively controlled by supplying Si to the plants (Datnoff et al., 2007; Rodrigues et al., 2009). For the pathosystem rice-Pyricularia grisea, Seebold et al. (2001) found that although the latent period did not differ between some rice cultivars with different levels of partial resistance, the incubation period was lengthened as the rates of calcium silicate increased in the soil. Indeed, the authors showed that there was a significant decrease in the infection efficiency, lesion size, rate of lesion expansion, sporulation per lesion and diseased leaf area on the rice plants supplied with Si (Seebold et al., 2001). Resende et al. (2009) reported 
Cytological aspects of the infection process of Pyricularia oryzae on leaves of wheat plants...

that the area under relative infection efficiency progress curve, area under anthracnose index progress curve and final disease severity were significantly decreased on the leaves of sorghum plants supplied with Si and infected with Colletotrichum sublineolum.

This study was carried out to evaluate the effect of $\mathrm{Si}$ on the cytological aspects arising from the infection process of $P$. oryzae on the leaves of wheat plants.

\section{MATERIALS AND METHODS}

\section{Nutrient solution preparation}

The nutrient solution used in this study was prepared based on Hoagland \& Arnon (1950) with some modifications and included the following macronutrients: $1.0 \mathrm{mM} \mathrm{KNO}_{3}, 0.25 \mathrm{mM} \mathrm{NH}_{4} \mathrm{H}_{2} \mathrm{PO}_{4}, 0.1 \mathrm{mM} \mathrm{NH}_{4} \mathrm{Cl}, 0.5$ $\mathrm{mM} \mathrm{MgSO}_{4}$ and $1.0 \mathrm{mM} \mathrm{Ca}\left(\mathrm{NO}_{3}\right)$; and the micronutrients: $0.30 \mu \mathrm{M} \mathrm{CuSO}_{4}, 0.33 \mu \mathrm{M} \mathrm{ZnSO}_{4}, 11.5 \mu \mathrm{M} \mathrm{H}_{3} \mathrm{BO}_{3}, 3.5$ $\mu \mathrm{M} \mathrm{MnCl}, 0.1 \mu \mathrm{M}\left(\mathrm{NH}_{4}\right) \cdot 6 \mathrm{Mo}_{7} \mathrm{O}_{2}, 25 \mu \mathrm{M} \mathrm{FeSO}_{4}$ and 25 $\mu \mathrm{M}$ EDTA. Silicon was supplied as silicic acid, which was prepared by passing potassium silicate through cationexchange resin (Amberlite IR-120B, $\mathrm{H}^{+}$form; SigmaAldrich). The Si rates used were 0 or $2 \mathrm{mM}$. Addition of silicic acid to the nutrient solution did not alter the $\mathrm{pH}$.

\section{Plant growth}

Wheat seeds from cultivar BR-18 were surface sterilized in $10 \%$ (vol/vol) $\mathrm{NaOCl}$ for $1.5 \mathrm{~min}$, rinsed in sterilized water for $3 \mathrm{~min}$ and germinated on distilled water-soaked germitest paper in a germination chamber at $25^{\circ} \mathrm{C}$ for six days. Germinated seedlings were transferred to plastic containers with one-half-strength of the nutrient solution without the presence of Si for two days. After this period, plants were transferred to new plastic containers with nutrient solution prepared with or without $\mathrm{Si}$. The aerated nutrient solution was changed every four days. The $\mathrm{pH}$ was checked daily and kept around 5.5 by using $\mathrm{NaOH}$ or $\mathrm{HCl}(1 \mathrm{M})$ when needed.

\section{Inoculation procedure}

The monosporic isolate of $P$. oryzae (UFV Po-1) was used to inoculate the plants. This isolate was preserved in glass vials containing autoclaved barley seeds (Urashima $\&$ Kato, 1994). Infected seeds were transferred to Petri dishes containing potato-dextrose-agar (PDA) media. After 3 days, PDA plugs containing fungal mycelia were transferred to new Petri dishes containing oat media. These Petri dishes were kept in a growth chamber at $25^{\circ} \mathrm{C}$ with a 12-h photoperiod for 10 days. After this period, conidia were carefully removed from the Petri dishes with a brush to obtain a conidial suspension. Plants were inoculated with a conidial suspension of $P$. oryzae $\left(10^{5}\right.$ conidia $\mathrm{mL}^{-1}$ ) at 35 days after emergence (growth stage 35) (Zadoks, 1974). A volume of $20 \mathrm{~mL}$ of suspension was applied as a fine mist to the adaxial leaf blades of each plant until runoff using a VL Airbrush atomizer (Paasche
Airbrush Co.). Gelatin (1\%, wt/vol) was added to the sterile water to aid conidial adhesion to the leaf blades. Immediately after inoculation, plants were transferred to a mist chamber at $25 \pm 2^{\circ} \mathrm{C}$, relative humidity of $90 \pm 2 \%$ and were subjected to an initial 24-h dark period. After this 24-h period, plants received a $12-\mathrm{h}$ photoperiod of $225 \mu \mathrm{mol} \mathrm{m} \mathrm{m}^{-2} \mathrm{~s}^{-1}$ provided by cool-white fluorescent lamps. Plants were kept inside the mist chamber for the duration of the experiments.

\section{Experimental design and data analysis}

Two independent experiments were carried out in a completely randomized design with two treatments (referred to as $-\mathrm{Si}$ and $+\mathrm{Si}$ plants) and ten replications to evaluate blast severity and foliar Si concentration. A third experiment, repeated once, was performed to obtain leaves for the cytological observations. A total of 40 plants were used in each experiment. Each experimental unit consisted of one plastic plot containing two plants. Data from all variables analyzed were combined for statistical analysis after determining the homogeneity of variance and mean square (Gomes \& Garcia, 2002) and subjected to analysis of variance and means of treatments were compared by $t$ test $(P \leq 0.05)$ using SAS software (SAS Institute, Inc.).

\section{Blast severity assessment}

Blast severity on the fourth, fifth and sixth leaves, from the base to the apex, of each plant per replication and treatment was scored at 72, 96 and 120 hours after inoculation (hai) using the diagrammatic scale proposed by Rios et al. (2013). Data from blast severity was used to calculate the area under blast progress curve (AUBPC) for each leaf of each plant per replication and treatment according to Shaner \& Finney (1977).

\section{Cytological observations}

In a separate experiment, a total of 80-100 leaf pieces, approximately $0.5 \mathrm{~cm}^{2}$ in size, were randomly collected from the fourth and fifth leaves, from the base to the apex, of each plant per replication and treatment at 24, 36, 48, 72 and 96 hai. Leaf pieces were fixed and decolorized in boiling $95 \%$ ethanol (vol/vol) for $15 \mathrm{~min}$ and after were cleared for three weeks in saturated chloral hydrate solution $\left(100 \mathrm{~g} \mathrm{~mL}^{-1}\right)$ (Sigma-Aldrich). Cleared leaf pieces were mounted adaxial side up on glass slides containing three drops of modified Hoyer's mounting medium (Cunningham, 1972). Fifty appressorial sites per replication and treatment were randomly examined in detail to determine the fungal development index (FDI) within the epidermal cell(s), the temporal outcome of $P$. oryzae-wheat interaction and the number and degree of browning of adaxial epidermal cells under a Axio Imager A1 microscope (400 × magnification; Carl Zeiss) equipped with differential interference contrast optics.

The FDI within epidermal cell(s) was determined based on the infection index developed by Takahashi 
(1956) and modified by Rodrigues et al. (2005) on leaf pieces collected at 24, 36, 48 and 72 hai. The infection index ranged from 0 to 4 where $0=$ conidium has formed an appressorium, but the infection hyphae has not been noticed within the epidermal cell, $0.5=$ the infection hyphae within the epidermal cell has a length shorter than the diameter of the appressorium, 1 = infection hyphae has a length greater than two times the diameter of the appressorium, 2 $=$ infection hyphae has a length greater than five times the diameter of the appressorium, but without any branching, 3 = infection hyphae has elongated within the epidermal cell forming a few branches and $4=$ fully developed infection hyphae within epidermal cell without extension to neighboring epidermal cells. The FDI greater than four corresponded to the sum of infection indexes of all ranges observed in epidermal cells neighboring the first penetrated epidermal cell.

The temporal outcome of $P$. oryzae-wheat interaction was grouped into three types according to Rodrigues et al. (2005): type A - absence of infection hyphae within epidermal cell underlying the appressorium, type B - successful penetration (infection hyphae within the epidermal cell and absence of cytoplasmic granulation) and type $\mathrm{C}$ - successful penetration (infection hyphae within the epidermal cell associated with intense cytoplasmic granulation). The frequency of each type of cellular reaction for the fifty appressorial sites examined per each replication and treatment was calculated.

The number and the degree of browning of adaxial epidermal cells for the fifty appressorial sites observed were also evaluated. The degree of browning of epidermal cells was grouped into three levels according to Rodrigues et al. (2005): level 1 - cell wall of epidermal cells showing no browning, level 2 - cell wall of epidermal cells palely yellowed and level 3 - whole-epidermal cells deeply browned with adjacent cells showing slightly brown cell wall.

\section{Determination of foliar Si concentration}

After the termination of the experiments, the first, second, seventh and eighth leaves on each plant (40-days old) of each replication and treatment were collected, washed in deionized water, dried for $72 \mathrm{~h}$ at $65^{\circ} \mathrm{C}$ and ground to pass through a 40-mesh screen using a Thomas-Wiley mill (Thomas Scientific). The foliar Si concentration was determined by colorimetric analysis of $0.1 \mathrm{~g}$ of dried and alkali-digested tissue (Debona et al., 2012) and expressed in dag $\mathrm{kg}^{-1}$.

\section{RESULTS}

\section{Foliar Si concentration and AUBPC}

The foliar Si concentration was significantly superior for the + Si plants in comparison to the -Si plants (1.62 and $0.36 \mathrm{dag} / \mathrm{kg}$, respectively). The AUBPC was significantly lower on the leaves of $+\mathrm{Si}$ plants than on the leaves of -Si plants (234.5 and 489.87, respectively).

\section{FDI}

The FDI was significantly lower for the + Si plants compared to the -Si plants at 48 and 72 hai (Figure 1). At 72 hai, hyphae of $P$. oryzae grew successfully and formed an extensively branched mycelium in the first-invaded epidermal cell and invaded many neighboring cells on the -Si plants (Figure 2). For the +Si plants, fungal hyphae was restricted to the first-invaded epidermal cell (Figure 2).

\section{Number of brown adaxial epidermal cells and intensity of browning}

The number of brown adaxial epidermal cells at the appressorial sites examined became visible at 48 hai for both $-\mathrm{Si}$ and $+\mathrm{Si}$ plants (Figure 3). However most of the cell walls became pale yellow and some slightly brown (category 2) at 48 hai for the -Si plants (Figure $4 \mathrm{~A}$ ), while for $+\mathrm{Si}$ plants, cell walls became slightly brown and pale yellow only at 72 hai (categories 2 and 3) (Figure 4B). The number of brown adaxial epidermal cells was significantly lower for the $+\mathrm{Si}$ plants compared to the -Si plants at 48, 72 and 96 (Figure 3). For both $-\mathrm{Si}$ and $+\mathrm{Si}$ plants, the increase in the frequency of infection sites showing browning (category 2) by 72 hai was followed by a sharp increase in the frequency of infection sites with whole epidermal cells deeply brown and adjacent cells with slightly brown cell walls (category 3 ) at 96 hai (Figure 4A,B). The frequency of infection sites showing browning (category 3 ) was higher for the -Si plants (Figure 4A) than for the + Si plants (Figure 4B). This can be explained due to the high frequency of apressorial sites exhibiting either no browning of the epidermal cell walls (category 1) or pale yellow or slightly brown cell walls (categories 2 and 3 ) for the -Si plants.

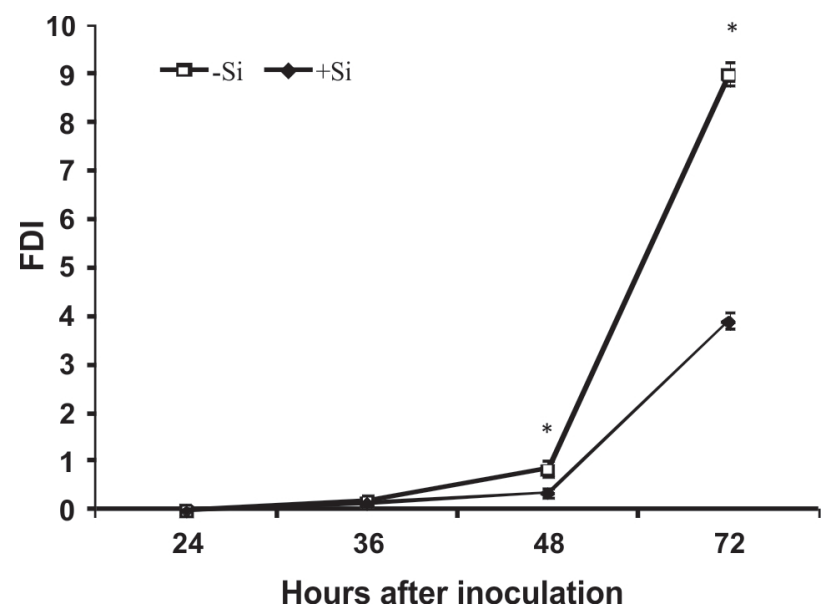

FIGURE 1 - Fungal development index (FDI) within adaxial epidermal cells on leaves of wheat plants grown in hydroponic culture containing $0 \mathrm{mM}(-\mathrm{Si})$ or $2 \mathrm{mM}(+\mathrm{Si})$ of silicon at different time-points after inoculation with Pyricularia oryzae. Error bars represent the standard deviation of means. Means from $-\mathrm{Si}$ and $+\mathrm{Si}$ treatments followed by an asterisk $\left(^{*}\right)$ are significantly different $(P$ $\leq 0.05$ ) by $t$-test. $n=20$. 

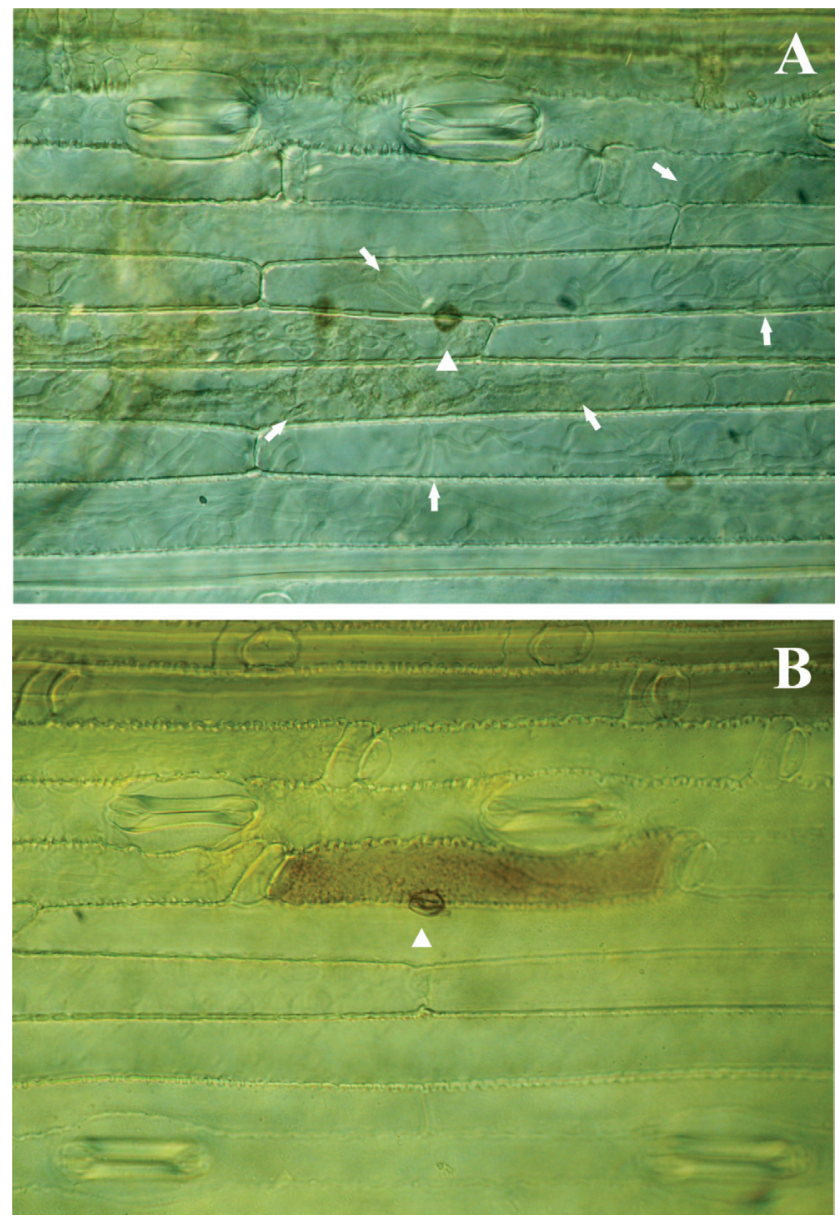

FIGURE 2 - Differential interference contrast microscopy of cleared epidermal cells on leaves of wheat plants grown in hydroponic culture containing $0 \mathrm{mM}(-\mathrm{Si})(\mathbf{A})$ or $2 \mathrm{mM}(+\mathrm{Si})$ of silicon (B) at 72 hours after inoculation with Pyricularia oryzae. A. well-developed invaded hyphae in the epidermal cell beneath the appressorium (arrowhead) producing several branches and colonizing neighboring epidermal cells (arrows) $(400 \times)$ on a leaf from the -Si plant. B. Fungal hyphae arised from an appressorium (arrowhead) within an epidermal cell show limited grow on a leaf from the + Si plant $(400 \times) . n=20$.

\section{Cellular responses of the epidermal cells to P. oryzae infection}

From 36 to 48 hai, some appressorial sites examined exhibited type $\mathrm{B}$ reaction (infection hyphae within the epidermal cell and absence of cytoplasm granulation) for both $-\mathrm{Si}$ and $+\mathrm{Si}$ plants, but with higher frequencies for the $-\mathrm{Si}$ plants (Figure 5A,B). The type $\mathrm{C}$ reaction (intense granulation of the cytoplasm of the invaded epidermal cell) occurred at 48 hai for only for the + Si plants simultaneously with reduction of the type A reaction (Figure 5B). A decrease in type A reaction from 72 to 96 hai was followed by an increase in the frequency of appressorial sites exhibiting type $\mathrm{B}$ and type $\mathrm{C}$ reactions for both $-\mathrm{Si}$ and $+\mathrm{Si}$ plants (Figure 5A,B). The frequency of appressorial sites showing type $\mathrm{B}$ reaction was lower for the $+\mathrm{Si}$ plants than for the

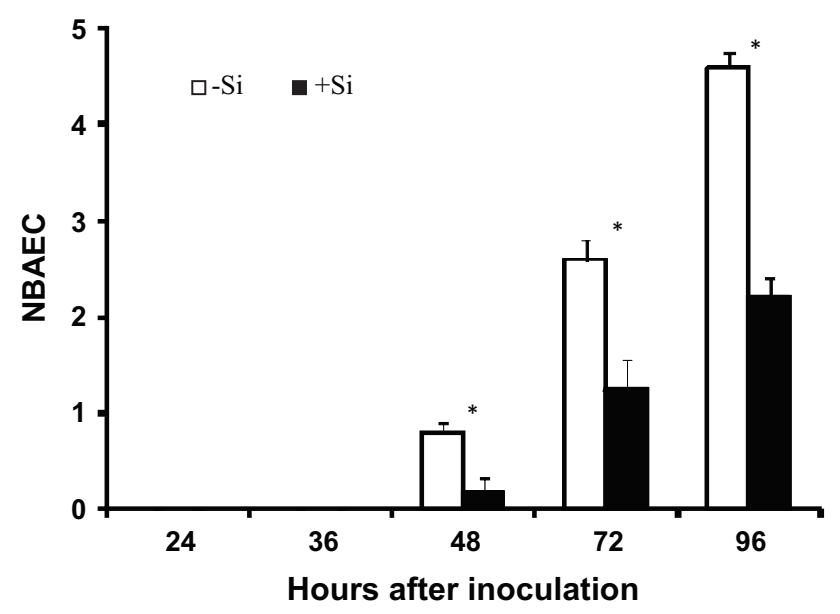

FIGURE 3 - Number of brown adaxial epidermal cells (NBAEC) on leaves of wheat plants grown in hydroponic culture containing $0 \mathrm{mM}(-\mathrm{Si})$ or $2 \mathrm{mM}(+\mathrm{Si})$ of silicon at different time-points after inoculation with Pyricularia oryzae. Error bars represent the standard deviation of means. $n=20$.

-Si plants at 72 and 96 hai. This can be explained due to the high frequency of appressorial sites showing type A reaction (unsuccessful penetration) was kept higher for the + Si plants (Figure 5A,B).

\section{DISCUSSION}

In support of previous findings that $\mathrm{Si}$ can improve the resistance of several monocots against foliar pathogens (Datnoff et al., 2007), including the wheat-P. oryzae interaction (Xavier Filha et al., 2011), the present study presents, to the best of our knowledge, the first cytological features associated with the increase in wheat resistance to blast mediated by Si.

The high foliar $\mathrm{Si}$ concentration contributed to decrease blast severity and at the cytological level reduced fungal growth inside the epidermal cells as well as the number of brown adaxial epidermal cells and their intensity of browning. Taking into consideration that $P$. oryzae needs to trigger necrosis to successfully colonize and sporulate on leaf tissues of wheat plants in the same pattern as $P$. oryzae in rice (Rodrigues et al., 2005), it is postulated that the higher number of brown adaxial epidermal cells for the -Si plants was the result of an unlimited fungal growth within them in contrast to the + Si plants, where fungal growth was greatly suppressed and restricted to few epidermal cells. It seems, therefore, that in areas of heavy $\mathrm{Si}$ deposition, such as below the cuticle and in the plant cell wall, fungal ingress was delayed and tissue colonization was reduced. It is plausible that the reduction in $P$. oryzae growth inside the epidermal cells of the + Si plants may be associated with a biochemical strategy of defense mediated by $\mathrm{Si}$ as reported by the rice-P. oryzae and wheat- $B$. g. f.sp. tritici interactions (Bélanger et al., 2003; Rodrigues et al., 2005). 

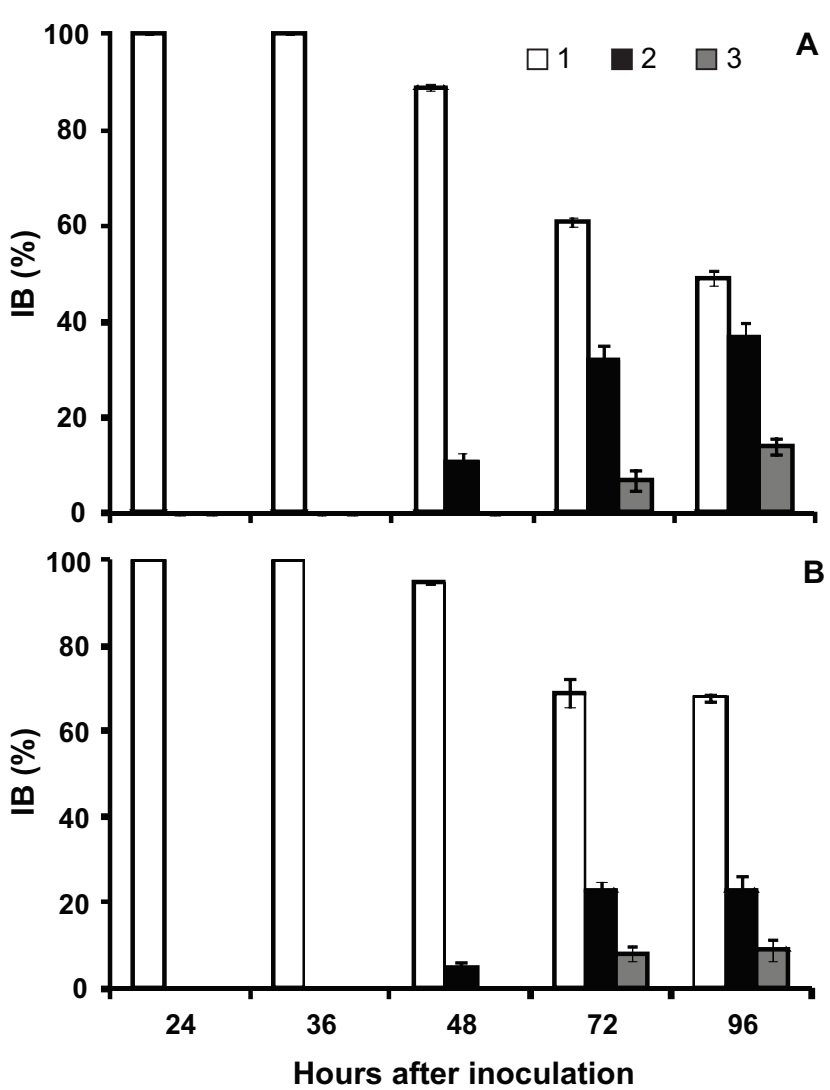

FIGURE 4 - Intensity of browning (IB) of adaxial epidermal cells on leaves of wheat plants grown in hydroponic culture containing 0 $\mathrm{mM}(-\mathrm{Si})(\mathbf{A})$ or $2 \mathrm{mM}(+\mathrm{Si})$ of silicon $(\mathbf{B})$ at different time-points after inoculation with Pyricularia oryzae. Error bars represent the standard deviation of means. $n=20$.

P. oryzae causes browning of epidermal cells, most likely due the action of the cytotoxic nonspecific toxins (Ou, 1985). Dallagnol et al. (2011) observed that the area under the brown spot progress curve for plants from cv. Oochikara (wild-type) and the mutant deficient in Si uptake (lsi1) was reduced in the presence of $\mathrm{Si}$. The reduced number of brown epidermal cells on the leaves from cv. Oochikara and the lsil mutant plants supplied with Si contributed to decreased lipid peroxidation and electrolyte leakage during the infection process of Bipolaris oryzae (Dallagnol et al., 2011).

The frequency of appressorial sites exhibiting no infection hyphae within the epidermal cell underlying the appressorium (type A reaction) was higher for the + Si plants than for the -Si plants. Rodrigues et al. (2005) reported high frequency of unsuccessful penetrations from $P$. grisea on rice leaves from + Si plants. Rice resistance to blast has been associated with the density of silicified cells in the leaf epidermis or the cuticle-silica double layer formed upon deposition and polymerization of monosilicic acid beneath the cuticle (Kim et al., 2002). It

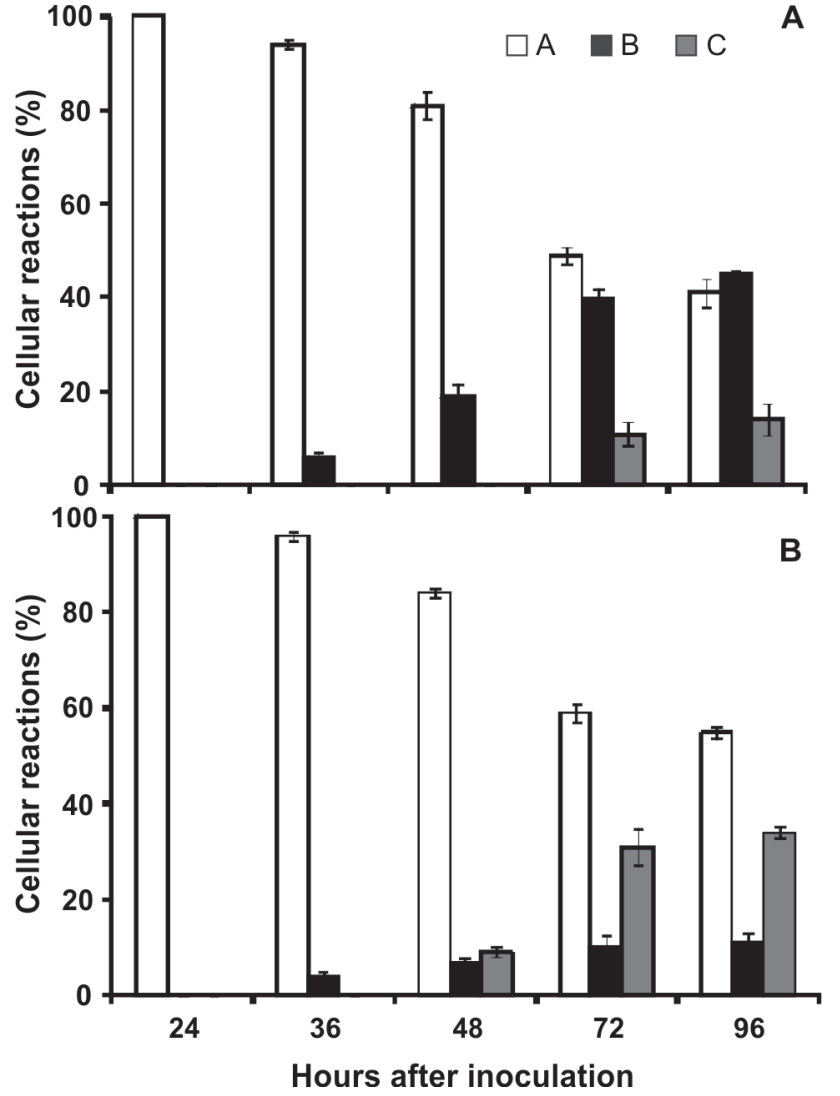

FIGURE 5 - Frequency of three types of cellular reactions in the adaxial epidermal cells on leaves of wheat plants grown in hydroponic culture containing $0 \mathrm{mM}(-\mathrm{Si})(\mathbf{A})$ or $2 \mathrm{mM}(+\mathrm{Si})$ of silicon (B) at different time-points after inoculation with Pyricularia oryzae. Error bars represent the standard deviation of means. $n=20$.

is known that apressoria from $P$. grisea cannot overcome the physical impediment created by the cuticle-silica double layer contributing to decrease the number of blast lesions (Seebold et al., 2001; Rodrigues et al., 2005). However, considering that the presence of silica cells and silica bodies are not uniformly distributed in the adaxial epidermis of rice leaves (Rezende et al., 2009), P. oryzae penetration and successful infection can take place explaining the unsuccessful penetrations in the epidermal cells of the $+\mathrm{Si}$ plants. According to Yoshida et al. (1962) a decrease in the number of blast lesions was attributed to the fact that some appressoria could not overcome the physical impedance conferred by the cuticle-silica double layer. Indeed, the heavy $\mathrm{Si}$ deposition on the cell wall of epidermal cells contributed to a delay in $P$. grisea ingress and provided the rice plant with enough time to activate biochemical mechanisms of defense to overcome fungal infection (Rodrigues et al., 2005).

This study provides novel cytological evidence of the positive effect of $\mathrm{Si}$ in affecting the infection process of 
Cytological aspects of the infection process of Pyricularia oryzae on leaves of wheat plants...

P. oryzae on leaves of wheat plants contributing, therefore, to reduce the blast symptoms.

\section{ACKNOWLEDGEMENTS}

F.A. Rodrigues thanks Conselho Nacional de Desenvolvimento Científico e Tecnológico - CNPq for his fellowship. M.F.A. Cruz was supported by the CNPq (PDJ Scholarship 503246/2012-3). This study was supported by grants from $\mathrm{CNPq}$ and Fundação de Amparo à Pesquisa do Estado de Minas Gerais - FAPEMIG to F.A. Rodrigues.

\section{REFERENCES}

Bélanger RR, Benhamou N, Menzies JG (2003) Cytological evidence of an active role of silicon in wheat resistance to powdery mildew (Blumeria graminis f.sp. tritici). Phytopathology 93:402412

Cunningham JL (1972) A miracle mounting fluid for permanent whole-mounts of microfungi. Mycologia 64:906-911.

Dallagnol LJ, Rodrigues FA, Mielli VBM, Pereira SC (2011) Deficiency in silicon uptake affects cytological, physiological, and biochemical events in the rice-Bipolaris oryzae interaction. Phytopathology 101:92-104.

Datnoff LE, Rodrigues FA, Seebold KW (2007) Silicon and Plant Disease. In: Datnoff LE, Elmer WH, Huber DM (Eds.) Mineral Nutrition and Plant Disease. St Paul MN, USA. APS Press. pp. 233-246.

Debona D, Rodrigues FA, Rios JA, Nascimento KJT (2012) Biochemical changes in the leaves of wheat plants infected by Pyricularia oryzae. Phytopathology 102:1121-1129.

Domiciano GP, Rodrigues FA, Vale FXR, Xavier Filha MS, Moreira WR, Andrade CCL, Pereira SC (2010) Wheat resistance spot blotch potentiated by silicon. Journal of Phytopathology 158:334-343.

Gomes PF, Garcia CH (2002) Estatística Aplicada a Experimentos Agronômicos e Florestais. Piracicaba SP, Brazil. FEALQ.

Goulart ACP, Sousa PG, Urashima AS (2007) Danos em trigo causados pela infecção de Pyricularia grisea. Summa Phytopathologica 33:358-363.

Hoagland R, Arnon I (1950) The water culture method for growing plants without soil. California Agricultural Experiment Station 347:1-32.

Igarashi S, Utiamada CM, Igarashi IC, Kazuma AH, Lopes RS (1986) Pyricularia em trigo. 1. Ocorrência de Pyricularia sp. no estado do Paraná. Fitopatologia Brasileira 11:351-352.

Kim SG, Kim KW, Park EW, Choi D (2002) Silicon-induced cell wall fortification of rice leaves, a possible cellular mechanism of enhanced host resistance to blast. Phytopathology 92:1095-1103.

Ou SH (1985) Rice Diseases. $2^{\text {nd }}$ Ed. Kew UK. CMI/AAB.
Rafi MM, Epstein E (1999) Silicon absorption by wheat (Triticum aestivum L). Plant and Soil 211:223-230.

Rémus-Borel W, Menzies JG, Bélanger RR (2005) Silicon induces antifungal compounds in powdery mildew-infected wheat. Physiological and Molecular Plant Pathology 66:108-115.

Resende RR, Rodrigues FA, Soares JM, Casela CR (2009) Influence of silicon on some components of resistance to anthracnose in susceptible and resistant sorghum lines. European Journal of Plant Pathology 124:533-541.

Rezende DC, Rodrigues FA, Carré-Missio V, SchurtDA, Kawamura IK, Korndörfer GH (2009) Effect of root and foliar applications of silicon on brown spot development in rice. Australasian Plant Pathology 38:67-73.

Rios JA, Debona D, Duarte HSS, Rodrigues FA (2013) Development and validation of a standard area diagram set to assess blast severity on wheat leaves. European Journal of Plant Pathology 136:603-611.

Rodgers-Gray BS, Shaw MW (2000) Substantial reductions in winter wheat diseases caused by addition of rice straw but not manure to soil. Plant Pathology 49:590-599.

Rodrigues FA, Datnoff LE, Korndörfer GH, Seebold KW, Rush MC (2001) Effect of silicon and host resistance on sheath blight development in rice. Plant Disease 85:827-832.

Rodrigues FA, Jurick WM, Datnoff LE, Jones JB, Rollins JA (2005) Silicon influences cytological and molecular events in compatible and incompatible rice-Magnaporthe grisea interactions. Physiological and Molecular Plant Pathology 66:144-159.

Seebold KW, Kucharek TA, Datnoff LE, Correa-Victoria FJ, Marchetti MA (2001) The influence of silicon on components of resistance to blast in susceptible, partially resistant and resistant cultivars of rice. Phytopathology 91:63-69.

Shaner G, Finney RE (1977) The effect of nitrogen fertilization on the expression of slow-mildewing resistance in Knox wheat. Phytopathology 67:1051-1056.

Takahashi Y (1956) Studies on the mechanism of resistance of rice plants to Piricularia oryzae. II. Pathological changes microscopically observed in host cells in which fungus hyphae do not grow well. Bulletin of the Yamagata University, Agricultural Sciences 2:37-51.

Urashima AS, Kato H (1994) Varietal resistance and chemical control of wheat blast fungus. Summa Phytopathologica 20:107112.

Xavier Filha MS, Rodrigues FA, Domiciano GP, Oliveira HV, Silveira PR, Moreira WR (2011) Wheat resistance to leaf blast mediated by silicon. Australasian Plant Pathology 40:28-38.

Yoshida SS, Ohnishi Y, Kitagishi K (1962) Histochemistry of silicon in rice plant. (III) The presence of cuticle-silica double layer in the epidermal tissue. Japanese Journal of Soil Science and Plant Nutrition 8:107-113.

Zadoks JC, Chang TT, Konzac CF (1974) A decimal code for the growth stages of cereals. Weed Research 14:415-421. 